International Business Management 13 (9): 366-370, 2019

ISSN: $1993-5250$

(C) Medwell Journals, 2019

\title{
Analysis Relative Strength Index and Earning per Share on Stock Price (Survey on LQ 45 Companies for the 2014-2016 Period)
}

\author{
Jajang Badruzaman \\ Department of Accounting, Faculty of Economic and Business, \\ Siliwangi University, Jawa Barat, Indonesia
}

\begin{abstract}
This study aims to determine the effect of the relative strength index and earnig per share on stock prices. The research design used is a quantitative approach with a population of all companies in the LQ45 category listed on the Indonesia stock exchange for the 2013-2016 periode. The sampling technique used was purposive sampling. Based on the criteria set, 13 companies were obtained. The results showed that the relative strength index and earning per share had a significant positive effect on stock prices in the LQ45 company on the Indonesia stock exchange for the period 2013-2016.
\end{abstract}

Key words: Relative Strength Index (RSI), Earning Per Share (EPS), stock price, purposive sampling, population, category

\section{INTRODUCTION}

Stock are letters of ownership of investor ownership in a company, the amount of ownership is determined by how much the funds invested by investors in the company. Furthermore, the investors in the process of making investments are inseparable from information, both quantitative and qualitative information. Therefore, the role of information in making investment decisions in the capital market is very important.

Investors in making investment decisions depend on the information received. The information received is analyzed through a fundamental analysis and technical analysis approach. Fundamental analysis is an analysis that uses financial statement data as well as economic events that influence it. Investors are very interested in current earnings information and future earnings potential and profit stability. So that, it can be predicted to what extent the potential of the company can return its investment. Furthermore, technical analysis is an analysis of testing past and present stock price data to predict stock prices in the future. The method used in conducting technical analysis is usually Moving Average (MA), Bollinger Band (BB), Relative Strength Index (RSI), Stochastic and Moving Average Convergence Divergence (MACD).

Based on these explanations researchers are interested in conducting research on the Analysis of the Relative Strength Index (RSI) and Earning Per Share (EPS) on stock prices for the period 2013-2016 in LQ45 companies on the Indonesia Stock Exchange (IDX).

\section{MATERIALS AND METHODS}

The stock price is the stock price that occurs in the secondary market at a certain time determined by market participants at the request and supply of shares. Investors in determining stock price requests first conduct an analysis of stock movements. The indicator used to calculate stock price movements is the closing price.

Relative strength index is a technical analysis that analyzes stock price fluctuations over a period of time. Company value is an investor's perception of the company which is often associated with stock prices. A high stock price will result in a high RSI value as well in the end the better the profits that investors get. The relative strength index is calculating the ratio between the magnitude of the difference in the rate of increase in price and the level of price decline in a certain time span. The RSI is generally, determined at the level of 30-70 points. If the RSI is at the level of 30 oversold or oversold indications. If the RSI at level 70 is overbought or overbought. Formulated formulas are:

$$
\mathrm{RSI}=100-\frac{100}{1+\mathrm{RS}}
$$

where:

$$
\mathrm{RS}=\frac{\text { Average increasing of closing price } \times \text { day }}{\text { Average decrease of closing price } \times \text { day }}
$$

With RSI we can find out whether a price is overbought or oversold. Thus, the analysis of the RSI will have an impact on stock prices. This is in line with previous research conducted by Hai-Ping and Pin (2013), Abbad et al., Singla (2015), Chong et al. (2014) and Bhargavi et al. (2017) that RSI positive effect on stock prices. 
Then the factors that influence stock prices other than RSI are Earning Per Share (EPS) which is a ratio that shows how much profit is gained from shares invested in the company. Earnings per share can be used as an indicator in measuring the level of success of the company. EPS is calculated by dividing net income after tax with the number of shares outstanding.

Thus EPS is very important for investors in measuring the success of the company. EPS can reflect the effectiveness and efficiency of a company in utilizing existing assets to make a profit. If high EPS will have an impact on investors to invest in the company. Investments made by investors in the form of purchases of company shares, but conversely if EPS is low, investors will not be interested in buying company shares.

The results of research conducted by Hunjra et al. (2014) in the sugar industry, chemical industry, food and personal care section and energy sectors as many as 63 companies listed on KSE showed EPS had a positive effect on stock prices. This research is supported by other studies namely Seetharaman and Raj (2011) who conducted research on banks in Malaysia found that there was a positive relationship between EPS and stock prices. Thus the stock price that occurs in the secondary market is influenced by information generated by internal factors and external factors. In internal factors in the form of financial statements which are an illustration of the realization of the company's operational activities that have been carried out while external factors are factors of investor behavior on stock demand and supply.

The research method used in this research is descriptive analysis method. The research object consists of the relative strength index, earning per share and stock price. Data used secondary data on LQ45 companies listed on the Indonesia Stock Exchange (IDX) from 2013-2016 Table 1.

The population in this study were all companies listed on LQ45 on the Indonesia Stock Exchange (IDX) during

Table 1: Sample of LQ45 company on the IDX for 2013-2016

\begin{tabular}{ll}
\hline Code & Issuer \\
\hline ADRO & Adaro Energy Tbk \\
AKRA & AKR Corporindo Tbk \\
ASII & Astra International, Tbk \\
BSDE & Bumi Serpong Damai Tbk \\
ICBP & Indofood CBP Sukses Makmur Tbk \\
INDF & Indofood Sukses Makmur, Tbk \\
KLBF & Kalbe Farma, Tbk \\
LSIP & PP London Sumatra Indonesia Tbk \\
PGAS & Perusahaan Gas Negara (Persero), Tbk \\
SMGR & Semen Indonesia Persero,Tbk \\
TLKM & Telekomunikasi Indonesia (Persero), Tbk \\
UNTR & United Tractors, Tbk \\
UNVR & Unilever Indonesia, Tbk \\
\hline
\end{tabular}

www.idx.com the period 2013-2016. The sampling technique uses a purposive sampling method. Based on the results of processing obtained as many as 13 companies that meet the research criteria. As for those who fulfill the criteria consist of:

Variable operationalization: In this study the following variables are operationalized:

- Independent variable consisting of relative strength index (X1) earning per share (X2)

- Dependent variables include average closing stock prices 10 days before and have been issued financial statements (Y)

Analisys data: Panel data is a combination of time series data and cross section data. The use of panel data will increase the number of observations, so that, it will increase the degree of freedom. In data processing carried out in this study using three approaches: common effect; fixed effect and random effect. Then to choose the right model in processing this panel data a model test is carried out in the form of: Chow test, Hausman test and Langrange Multiplier (LM) test.

\section{RESULTS AND DISCUSSION}

Model testing: The first test is the Chow test, this test is done to choose whether the estimation is done using the common effect model or the fixed effect model. Based on the Chow test on the data shows that regression estimation is better done using fixed effect.The results of the Chow test in Table 2 show that the probability of cross section $\mathrm{F}<0.05$ which means deciding the use of fixed effects, the next step is to test the selection of estimates between fixed effects and random effects using the Hausman test.

The Hausman test results in Table 3 show that the cross-section probability is $>0.05$ which means it shows the use of random effects. This shows that regression estimation is better done using the random effect method. This result is in line with the Chow test and hausman test which states that the chosen model of the three most likely models is the random effect model. The next step is to do the Larange multiplier estimation test where the results of this test will determine the end of the model to be used.

The results of the Larange multiplier test in Table 4 show that the value of the cross section probability $<0.05$ which means that the use of random effects is better. Of the three panel data regression models, only common effects and fixed effects allow heterocedasticity while random effects do not occur. This is because the 
estimation of common effects and fixed effects still uses the Ordinary Least Square (OLS) approach while the random effect uses Generalized Least Square (GLS) which is one of the regression healing techniques for heterocedasticity. After getting the right model to estimate regression, the next step is to estimate regression using random effects. For the regression results as in Table 5.

Based on the results of the analysis using Eviews 10 in Table 5, the results show that the Relative Strength Index (RSI) and earning per share variables affect the stock price as illustrated in the formula that can be generated based on the analysis results as follows:

$$
\mathrm{Y}=2.488977+0.299 \mathrm{X} 1+0.868 \mathrm{X} 2
$$

where:

$$
\begin{array}{ll}
\mathrm{Y} & : \text { Stock price } \\
\alpha & : 2.488977 \\
\mathrm{X} 1 \text { (RSI) } & : 0.299 \\
\mathrm{X} 2 \text { (EPS) } & : 0.868
\end{array}
$$

From the regression equation above it can be concluded that the relative strength index and earnings per share variables have a significant positive effect on stock prices. This shows that each addition of the RSI and EPS values will cause an increase in the stock price.

Test $F$ statistics: The statistical test result $F$ shows the prob value. F (Statistics) is 0.0000 smaller than the significance level of 0.05 , so, it can be concluded that the regression model that is estimated to be feasible is used to explain the effect of the relative strength index variables and earnings per share on stock prices.

Significance t-test: $t$ significance test is used to analyze the effect of independent variables on the dependent variable. The value of prob t-stat from the independent variable RSI of $0.0301<0.05$, so that, the RSI variable has a significant effect on the dependent variable stock price at alpha $5 \%$ or in other words, the relative strength index has a significant effect on stock prices in listed companies in LQ45 with a 95\% confidence level. Furthermore, the EPS variable is $0.0000<0.05$, so that, the EPS variable has a significant effect on the dependent variable of stock price at alpha $5 \%$ or in other words Earning Per Share (EPS) has a significant effect on stock prices in companies registered with LQ45 listed on the exchange Indonesian securities (IDX) with a 95\% confidence level Table 6-8.

The coefficient of determination can be measured by the value of $R^{2}$. Based on the results of data processing with the random effect model, it is known that $R^{2} 0.65$

Table 2: Chow test

\begin{tabular}{lrll}
\hline Effects test & Statistic & df & Prob. \\
\hline Cross-section F & 20.935975 & $(12.37)$ & 0.0000 \\
Cross-section Chi-square & 106.748031 & 12 & 0.0000 \\
\hline Output Eviews & & &
\end{tabular}

Table 3: Hausman test

\begin{tabular}{llll}
\hline Test summary & $\chi^{2}$ statistic & $\chi^{2} \mathrm{df}$ & Prob. \\
\hline Cross-section random & 2.046097 & 2 & 0.3595 \\
\hline
\end{tabular}

Output Eviews

Table 4: Larange multiplier

\begin{tabular}{lccc}
\hline Variable & Test hypothesis & & \\
& Cross-section & Time & Both \\
\hline Breusch-Pagan & 110.2017 & 2.133215 & 112.3349 \\
& $(0.0000)$ & $(0.1441)$ & $(0.0000)$ \\
\hline
\end{tabular}

Output Eviews

Table 5: Results of regression with random effect method

\begin{tabular}{llccl}
\hline Variable & Coefficient & SE & t-Statistic & Prob. \\
\hline C & 2.488977 & 0.756165 & 3.291577 & 0.0019 \\
LOG(RSI) & 0.298888 & 0.133801 & 2.233821 & 0.0301 \\
LOG(EPS) & 0.868409 & 0.092069 & 9.432193 & 0.0000 \\
\hline
\end{tabular}

Output Eviews

Table 6: RSI of companies at LQ45 Period 2013-2016

\begin{tabular}{llllll}
\hline Code & Companies & 2013 & 2014 & 2015 & 2016 \\
\hline ADRO & Adaro Energy Tbk & 38.24 & 64.81 & 42.65 & 59.3 \\
AKRA & AKR Corporindo Tbk & 29.27 & 27.66 & 62.7 & 37.84 \\
ASII & Astra International, Tbk & 64.86 & 58.18 & 52.13 & 60.24 \\
BSDE & Bumi Serpong Damai, Tbk & 28.95 & 46.81 & 59.2 & 45.37 \\
ICBP & Indofood CBP Sukses Makmur Tbk & 58.33 & 69.64 & 56.36 & 50 \\
INDF & Indofood Sukses Makmur, Tbk & 50 & 50 & 58.56 & 52.88 \\
KLBF & Kalbe Farma, Tbk & 55.17 & 57.47 & 46 & 45.78 \\
LSIP & PP London Sumatra Indonesia Tbk & 54.24 & 50 & 60.38 & 45.97 \\
PGAS & Perusahaan Gas Negara (Persero), Tbk & 27.78 & 51.28 & 52.6 & 52.48 \\
SMGR & Semen Indonesia Persero, Tbk & 81.4 & 41.67 & 57.64 & 54.05 \\
TLKM & Telekomunikasi Indonesia (Persero), Tbk & 55.56 & 45.83 & 62.41 & 54.17 \\
UNTR & United Tractors, Tbk & 56.06 & 40 & 51.08 & 41.33 \\
UNVR & Unilever Indonesia, Tbk & 51.92 & 56.35 & 52.5 & 37.28 \\
\hline
\end{tabular}


Int. Business Manage., 13 (9): 366-370, 2019

Table 7: EPS of company at LQ45 period 2013-2016

\begin{tabular}{|c|c|c|c|c|c|}
\hline Code & Companies & 2013 & 2014 & 2015 & 2016 \\
\hline$\overline{\mathrm{ADRO}}$ & Adaro Energy Tbk & 88.7 & 69.17 & 65.74 & 140.56 \\
\hline AKRA & AKR Corporindo Tbk & 167.04 & 206.99 & 262.36 & 253.22 \\
\hline ASII & Astra International, Tbk & 479.63 & 473.8 & 357.31 & 374.37 \\
\hline BSDE & Bumi Serpong Damai Tbk & 166.06 & 217.53 & 122.17 & 105.86 \\
\hline ICBP & Indofood CBP Sukses Makmur Tbk & 381.63 & 446.62 & 514.62 & 308.73 \\
\hline INDF & Indofood Sukses Makmur, Tbk & 285.16 & 442.5 & 338.02 & 472.02 \\
\hline KLBF & Kalbe Farma, Tbk & 37.8 & 44.05 & 42.76 & 49.06 \\
\hline LSIP & PP London Sumatra Indonesia Tbk & 112.78 & 134.36 & 91.36 & 87.04 \\
\hline PGAS & Perusahaan Gas Negara (Persero), Tbk & 435.56 & 370.78 & 242.58 & 168.67 \\
\hline SMGR & Semen Indonesia Persero, Tbk & 965.37 & 938.35 & 762.28 & 762.3 \\
\hline TLKM & Telekomunikasi Indonesia (Persero), Tbk & 140.92 & 145.22 & 153.66 & 171.93 \\
\hline UNTR & United Tractors, Tbk & 1295.85 & 1439.52 & 1033.07 & 1341.03 \\
\hline UNVR & Unilever Indonesia, Tbk & 701.52 & 752.1 & 766.95 & 837.57 \\
\hline
\end{tabular}

Table 8: Average of stock price at LQ45 companies period 2013-2016

\begin{tabular}{llllll}
\hline CODE & COMPANIES & 2013 & 2014 & 2015 & 2016 \\
\hline ADRO & Adaro Energy Tbk & 1.090 & 1.040 & 515 & 1.695 \\
AKRA & AKR Corporindo Tbk & 4.375 & 4.120 & 7.175 & 6.000 \\
ASII & Astra International Tbk & 6.800 & 7.425 & 6.000 & 8.275 \\
BSDE & Bumi Serpong Damai Tbk & 1.290 & 1.805 & 1.800 & 1.755 \\
ICBP & Indofood CBP Sukses Makmur Tbk & 10.200 & 13.100 & 13.475 & 8.575 \\
INDF & Indofood Sukses Makmur Tbk & 6.600 & 6.750 & 5.175 & 7.925 \\
KLBF & Kalbe Farma Tbk & 1.250 & 1.830 & 1.320 & 1.515 \\
LSIP & PP London Sumatra Indonesia Tbk & 1.930 & 1.890 & 1.320 & 1.740 \\
PGAS & Perusahaan Gas Negara (Persero) Tbk & 4.475 & 6.000 & 2.745 & 2.700 \\
SMGR & Semen Indonesia Persero Tbk & 14.150 & 16.200 & 11.400 & 9.175 \\
TLKM & Telekomunikasi Indonesia (Persero) Tbk & 2.150 & 2.865 & 3.105 & 3.980 \\
UNTR & United Tractors Tbk & 19.000 & 17.350 & 16.950 & 21.250 \\
UNVR & Unilever Indonesia Tbk & 26.000 & 32.300 & 37.000 & 38.800 \\
\hline
\end{tabular}

shows that the proportion of the influence of the relative strength index variable and earning per share on the stock price is $65 \%$. Then the influence of another variable of $35 \%$ is thought to influence the volume of stock trading, return on investment, return on equity and national economic development.

Then partially the relative strength index has a significant positive effect on stock prices in LQ45 companies registered in the Indonesian securities Stock Exchange (IDX) for the 2013-2016 period, this is in line with the results of research by Hai-Ping and Pin (2013); Abbad et al.; Singla (2015) Chong et al. (2014) and Bhargavi et al. (2017). Furthermore, earning per share has a significant effect on stock prices in LQ45 companies listed on the Indonesia Stock Exchange (IDX) for the 2013-2016 period in accordance with the results of research by Hunjra et al. (2014), Seetharaman and Raj (2011).

\section{CONCLUSION}

Based on the discussion that has been stated previously, it shows that the relative strength index and earning per share have a significant effect on stock prices in companies registered with LQ45 companies listed on the Indonesia Stock Exchange (IDX) for the period 2013-2016.

\section{REFERENCES}

Bhargavi. R., S. Gumparthi and R. Anith, 2017. Relative strength index for developing effective trading strategies in constructing optimal portfolio. Int. J. Applied Eng. Res., 12: 8926-8936.

Chong, T.T.L., W.K. Ng and V.K.S. Liew, 2014. Revisiting the performance of MACD and RSI oscillators. J. Risk Financial Manage., 7: 1-12.

Hai-Ping, H., and W. Pin, 2013. Optimization study of rsi expert system based on shanghai securities market. J. Theor. Applied Inf. Technol., 48: 1032-1039.

Hunjra, A.I., M.S. Ijaz, M.I. Chani, S. Hassan and U. Mustafa, 2014. Impact of dividend policy, earning per share, return on equity, profit after tax on stock prices. Int. J. Econ. Empirical Res., 2: 109-115. 
Int. Business Manage., 13 (9): 366-370, 2019

Seetharaman, A. and J.R. Raj, 2011. An empirical study on the impact of earnings pers hare on stock prices of a listed bank in Malayasia. Int. J. Applied Econ. Finance, 5: 114-126.
Singla, R., 2015. Prediction from technical analysis-a study of Indian stock market. Int. J. Eng. Technol. Manage. Applied Sci., 3: 198-202. 